\title{
The Effect of Filtration with Natural Esker Sand on the Removal of Organic Carbon and Suspended Solids from the Effluent of Experimental Recirculating Aquaculture Systems
}

\author{
Antti-Jussi Lindroos • Petra Lindholm-Lehto • \\ Jani Pulkkinen • Tapio Kiuru • Jouni Vielma
}

Received: 13 December 2019 / Accepted: 8 April 2020 / Published online: 24 April 2020

(C) The Author(s) 2020

\begin{abstract}
We studied the effect of sand filtration with natural esker material on the removal of total organic carbon (TOC), total suspended solids (TSS), and turbidity from the effluent of an experimental recirculating aquaculture system (RAS) farm. Separate experiments were performed with the same esker sand: (1) a soil column experiment in 2017 where the effluent (mean TOC $8.14 \mathrm{mg} \mathrm{L}^{-1}$ ) was percolated vertically through a $50-\mathrm{cm}$-thick sand column with the infiltration $1 \mathrm{~m} \mathrm{day}^{-1}$; (2) a sand filtration experiment with watersaturated conditions in 2018 where the effluent from the woodchip denitrification (mean TOC $26.84 \mathrm{mg} \mathrm{L}^{-1}$ ) was infiltrated through a sand layer with the retention time of 1.2 days. In experiment 2, infiltration of $25 \mathrm{~L} \mathrm{day}^{-1}$ through a $31-\mathrm{cm}$ sand layer and $40 \mathrm{~L}_{\text {day }}{ }^{-1}$ through a $50-\mathrm{cm}$ sand layer were studied. Both experiments were performed in association with rainbow trout (Oncorhynchus mykiss) grow-out trials. In sand filtration with vertical water flow through a soil column, the removal of TSS was $40 \%$, while of TOC $6 \%$, partly due
\end{abstract}

Electronic supplementary material The online version of this article (https://doi.org/10.1007/s11270-020-04589-9) contains supplementary material, which is available to authorized users.

\footnotetext{
A.-J. Lindroos

Natural Resources, Natural Resources Institute Finland (Luke), Latokartanonkaari 9, FI-00790 Helsinki, Finland

P. Lindholm-Lehto $(\bowtie) \cdot$

. Pulkkinen $\cdot$ T. Kiuru $\cdot$ J. Vielma

Aquatic Production Systems, Natural Resources Institute Finland (Luke), Survontie 9A, FI-40500 Jyväskylä, Finland

e-mail: petra.lindholm-lehto@luke.fi
}

to the small thickness of the soil column and coarse sand material. In water-saturated conditions, mean removal of TOC ( $\left.3 \mathrm{mg} \mathrm{L}^{-1} 1.2 \mathrm{day}^{-1}\right)$, TSS (1.2 mg L 1.2 day $\left.^{-1}\right)$, and turbidity $\left(0.4\right.$ FTU 1.2 day $^{-1}$ ) reached $11 \%$ (TOC), $18 \%$ (TSS), and 15\% (turbidity), even with the retention time of only 1.2 days. The removal of TOC in water-saturated conditions correlated with the removal of TSS and turbidity.

Keywords Effluent · Recirculating aquaculture system (RAS) · Total organic carbon (TOC) · Total suspended solids (TSS) · Turbidity · Sand filtration

\section{Introduction}

Infiltration of water through sand and gravel containing soil layers often improves the water quality by removing dissolved and particulate organic matter from the water. This can be seen in natural environments, e.g., in forest soils; the water is enriched with dissolved organic matter (DOM) when infiltrating through the tree canopy layer and organic layer of the forest soil, and DOM is removed from the percolation water in soil with increasing depth (Lindroos et al. 2008; Piirainen 2002; Piirainen et al. 2002; Starr and Ukonmaanaho 2004). Retention of dissolved organic carbon into the sandy soil for example, in the podzolization processes, due to the physical and chemical retention as well as biological degradation is important for the formation of natural groundwater reserves with low content of dissolved organic carbon (Lindroos et al. 2016; Michalzik et al. 2001; 
Ukonmaanaho et al. 2014; $\mathrm{Wu}$ et al. 2010). In the Nordic countries, groundwater reserves of good quality can typically be found in the esker areas dominated by glaciofluvial sand and gravel deposits (e.g., Lindroos et al. 2002; Nöjd et al. 2009). Water infiltration through the buffer zones (uncut forests, undisturbed soil) along watercourses can also be important for the removal of suspended solids (Ring et al. 2018, 2019) and thus improve the water quality.

Infiltration of water through the sand and gravel layers is also a widely used method in artificial recharge of groundwater (ARG) (e.g., Frycklund 1995, 1998; Frycklund and Jacks 1997; Peters et al. 1998). In the ARG process, surface water (lake or river water), which contains higher dissolved organic carbon (DOC) concentration than is allowed in household water, is infiltrated through the sand and gravel layers by basin or sprinkling infiltration in order to form artificial groundwater. In this process, there is an efficient removal of DOC and particulate organic matter (Kolehmainen et al. 2009; Lindroos et al. 2002). For example in Finland, the DOC level of about $10 \mathrm{mg} \mathrm{L}^{-1}$ in the infiltrated lake water has been decreased to less than $2 \mathrm{mg} \mathrm{L}^{-1}$ in ARG (Lindroos et al. 2002). The ARG process is a widely used method in drinking water production in the Nordic countries (Helmisaari et al. 1998; Kolehmainen et al. 2008). The removal of organic carbon from the infiltrated water is essential because chlorine disinfection of water may cause the formation of carcinogenic or mutagenic compounds as well as the organic matter may promote bacterial growth in water (Kivimäki et al. 1998; Gopal et al. 2007; Alver et al. 2018). In addition to chlorination, there are other methods available to remove natural organic matter, such as ozonation, adsorption, and catalytically enhanced ozonation (Matilainen and Sillanpää 2010; Bhatnagar and Sillanpää 2017; Alver and Kiliç 2018). Furthermore, humic substances may interact with less soluble pollutants (Thurman 1985).

In recirculating aquaculture system (RAS), fish is produced in circulating water, treating and reusing the water, with the need of typically $1-5 \%$ day $^{-1}$ of clean water added to the system. The intensity of the water recirculation is typically determined by the volume of added clean water per unit mass of feed used daily and in RASs, it often ranges from 500 to $1000 \mathrm{~L}$ of water $\mathrm{kg}^{-1}$ feed. In comparison, flow-through farms use up to $50,000 \mathrm{~L}$ of clean water $\mathrm{kg}^{-1}$ feed. Although particulate matter is removed to improve the water quality, fish feed and feces are sources of accumulating organic matter in the system (Dalsgaard and Pedersen 2011). Additionally, water source from a natural water body acts as a source of organic material, such as humic substances (Akkanen et al. 2004).

Sand filtration has widely been used for many purposes to improve the water quality, but the effectiveness and usefulness of sand filtration have rarely been studied for the removal of particulate and dissolved organic matter from the fish farm effluents. Sand filtration would not be technically possible in traditional flowthrough farms due to the large effluent volume, but the intense use of water in RAS farming may allow the use of sand filtration as a part of effluent treatment system. Freshwater aquaculture uses natural lake or river water, which contains humus compounds (e.g., hydrophilic and hydrophobic acids, bases, and neutrals; Lindroos et al. 2002). The total organic carbon (TOC) concentration increases in water when it is used in aquaculture e.g. due to fish food and emissions from farming. Sand filtration would probably be an effective method for the removal of TOC and suspended solids as well as for the removal of turbidity also in the fish farms. However, because the origin and composition of particulate and dissolved organic matter in RAS effluents differ at least partly from that in lake water, the behavior of total suspended solids (TSS) and TOC in RAS effluents during sand filtration might not be identical to that in lake water (ARG process). Therefore, it is important to study how effective sand filtration would be for RAS farm effluents. The removal of organic matter load would be important in the case when effluent water from the fish farms is released back to the natural river or lake or it may have an effect on groundwater.

The aim of this study was to determine the effect of sand filtration with natural esker material on the removal of TOC, TSS, and turbidity from the effluent of a RAS farm. For this purpose, we performed two separate experiments with the same esker sand: (1) a soil column experiment with vertical water flow and (2) a sand filtration experiment with water-saturated conditions. Both experiments with effluent water were performed in association with experimental RAS rearing rainbow trout (Oncorhynchus mykiss). We used naturally formed glaciofluvial esker sand without any pretreatment of the sand in order to study if local soil materials can be used as such at low costs. We hypothesized that there would be a removal of TOC, TSS, and turbidity from the 
effluent of the RAS in sand filtration with natural esker sand in either or both in unsaturated vertical water flow or in water-saturated conditions.

\section{Materials and Methods}

The sand filtration experiments were performed in 2017 (experiment 1) and 2018 (experiment 2) in the Natural Resources Institute Finland (Luke) Laukaa fish farm where separate recirculating aquaculture systems are operated for research purposes.

Inlet water to the experimental RAS was taken from surface water of an oligotrophic Lake Peurunka (area of $694 \mathrm{ha}, 60,000 \mathrm{~m}^{3}$ ) used as the clean replacement water. General water quality parameters of Lake Peurunka have been listed in Table 1.

Sand material for the sand filtration experiments was originated from the esker area, Häkinharju. This esker formation with glaciofluvial sand and gravel is located only a few kilometers from the aquaculture farm. The mean grain size of the used sand varied in the esker $0.7-1.3 \mathrm{~mm}$ (d50), classified as coarse sand $(0.6-2.0 \mathrm{~mm})$. The sand material was sorted, and the mean effective porosity $\left(\mathrm{n}_{\mathrm{e}}\right)$ was $0.35(0.32-0.37)$. Hydraulic conductivity was estimated to be about $20 \times 10^{-4} \mathrm{~m} \mathrm{~s}^{-1}$. During the formation of the esker after the last glaciation in Finland about 10,000 years BP (Eronen 1983), sand material was deposited and thoroughly leached by the melting waters of the ice sheet. This sedimentation process deposited geochemically even quality sand layers, in which the mineralogical composition is granitic, and quartz and feldspar are the dominating minerals. Small amount of dark mafic minerals and micas indicated that the release of

Table 1 Water quality of Lake Peurunka, depths of $5 \mathrm{~m}$ and $10 \mathrm{~m}$ (Hertta database, ELY Central Finland/Centre for Economic Development, Transport and the Environment)

\begin{tabular}{lll}
\hline Alkalinity & 0.2 & $\mathrm{mmol} \mathrm{L}^{-1}$ \\
COD $_{\mathrm{Mn}}$ & $6.8-7.4$ & $\mathrm{mg} \mathrm{L}^{-1}$ \\
Conductivity & $3.7-4.3$ & $\mathrm{mS} \mathrm{m}^{-1}$ \\
Dissolved oxygen & $6.2-11.8$ & $\mathrm{mg} \mathrm{L}^{-1}$ \\
Turbidity & $0.36-2.0$ & $\mathrm{FNU}$ \\
$\mathrm{pH}$ & $6.8-7.3$ & \\
\hline
\end{tabular}

elements from the sand in weathering is low (e.g. Starr and Lindroos 2006).

2.1 Experiment 1: Sand Filtration with Vertical Water Flow

The experimental RAS used in the first experiment consisted of twenty identical 450 -L bottom-drained rearing tanks with a shared water treatment system (Fig. 1). Water treatment system included a drum filter with $60-\mu \mathrm{m}$ mesh size (Faivre F2-80, France), two moving bed biofilters (MBBF) (680 L of carrier media per reactor) with RK Bioelements heavy $\left(750 \mathrm{~m}^{2} \mathrm{~m}^{-3}\right.$ ) carrier medium, RK Plast (A/S Denmark), and a fluidized sand filter (CycloBio, Marine Biotech, USA) filled with fine sand. Additionally, a carbon dioxide stripper (a cascade column, filled with polypropylene plastic balls, $\varnothing 50 \mathrm{~mm})$ was used and a UV disinfection system $(4 \times$ 220 W UV light bulbs, Skjölstrup \& Grönborg, Denmark). The RAS was operated with a daily feed load of $3-5 \mathrm{~kg} \mathrm{day}^{-1}$ and relative water renewal rate was set at $1000 \mathrm{~L} \mathrm{~kg}^{-1}$ feed. $\mathrm{pH}$ was maintained at 7.2 and controlled by adding sodium bicarbonate and dolomite.

Sand columns used in the experiment were $50 \mathrm{~cm}$ in height and $80 \mathrm{~cm}$ in diameter. Effluent from the RAS was sprinkled continuously onto the surface of the sand columns at a rate of $340 \mathrm{~mL} \mathrm{~min}^{-1}$, which correspond to the infiltration of $1 \mathrm{~m}^{3} \mathrm{~m}^{-2}$ day ${ }^{-1}$. Two soil columns were used in the experiment, both containing natural glaciofluvial coarse sand from a nearby source (see above). Infiltration water (input, effluent water from the RAS) and sand-filtrated water (water percolated vertically through the sand column) were sampled during the following 2 months after the start of the experiment. The first sampling date was on the 28th of June and the last 24th of August 2017. The first sampling was performed 1 week after the start of the experiment. The first three samples from the infiltration and sand-filtrated water were taken at 1-week interval from the beginning of the experiment. Later, there was a 3-week break in the infiltration because the experiment was performed as a part of normal aquaculture operations and during this period, no infiltration could be done. Infiltration through the soil columns was started again in August, and two samplings were performed at 1-week intervals. TOC, TSS, and turbidity were determined from the infiltration and sand-filtrated water samples. TOC $\left(\mathrm{mg} \mathrm{L}^{-1}\right)$ was determined by a TOC analyzer (SF-EN 1484:1997), TSS (GF/C, $\mathrm{mg} \mathrm{L}^{-1}$ ) by the 
Fig. 1 Flowchart of the RAS setup, showing a fish rearing tank (FT), drum filter (DF), moving bed biofilter (MBBF), sand-filled biofilter (SFBF), and a cascade aeration column (TF), followed by UV treatment

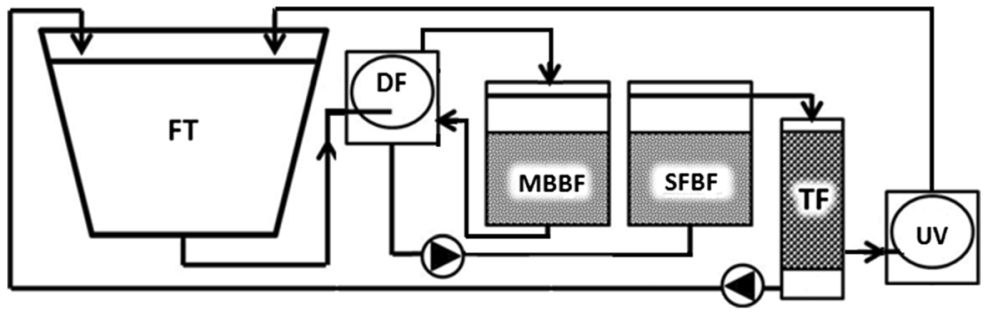

standard method SFS-EN 872:2005, and turbidity (FTU) by the standard method SFS-EN ISO 70271:2016.

\subsection{Experiment 2: Sand Filtration with Water-Saturated Conditions}

In the second experiment, the experimental RAS consisted of two individual units, each with a 500-L fish tank and a water treatment system with total water volume of $1000 \mathrm{~L}$. Solids removal system included a waste feed collector and a swirl separator. In the present trial, an up-flow fixed-bed bioreactor $(125 \mathrm{~L})$ and moving bed bioreactor $(125 \mathrm{~L}$ ) both filled with $70 \mathrm{~L}$ of $\mathrm{RK}$ Bioelements heavy $\left(750 \mathrm{~m}^{2} \mathrm{~m}^{-3}\right)$ carrier material which were stabilized to full maturity prior to start of the trial. Dissolved carbon dioxide was removed from the water by forced-ventilated cascade aeration column, with BioBlok 200 (EXPO-NET Danmark A/S, Denmark) filter media. Each system was monitored with a spectrometer probe (spectro::lyser, s::can, Vienna, Austria) to determine TOC, turbidity, and TSS. Additionally, turbidity was measured by a laboratory turbidity test $(0-100$ NTU, Hach 2100Q Turbidimeter, USA).

Part of the circulating water was led either to a small side loop $\left(25 \mathrm{~L} \mathrm{day}^{-1}\right)$ or a large side loop $\left(40 \mathrm{~L} \mathrm{day}^{-1}\right)$ for denitrification and infiltration (Fig. 2). For $25 \mathrm{~L} \mathrm{day}^{-1}$, a sand layer used in the experiment was $31 \mathrm{~cm}$ thick, and it was placed in a cylinder (diameter $60 \mathrm{~cm}$ ). Water was sprinkled continuously onto the surface of the sand layer, and a $25-\mathrm{cm}$ part of the sand layer was kept continuously water saturated by adjusting the outflow of water from the sand-filled cylinder. Similarly, $40 \mathrm{~L}^{\text {day }}{ }^{-1}$ of circulating water was infiltrated through a 50-cm-thick sand layer (water-saturated thickness $40 \mathrm{~cm}$ ). The retention time of the infiltrated water in both $25 \mathrm{~L}$ day $^{-1}$ and $40 \mathrm{~L}$ day $^{-1}$ infiltrations was 1.2 days. Before infiltration through the sand material, the water was first led to a woodchip bioreactor. The woodchip bioreactor containing unbarked silver birch (Betula Pendula) woodchips $(<5 \mathrm{~mm}$ ) acted as a carbon source for denitrification, aiming at nitrogen removal from the circulating system (Lindholm-Lehto et al. 2020; Pulkkinen et al. 2018).

After the denitrification, circulating water was infiltrated through the sand material by sprinkling onto the surface of sand layer. Two replicate RAS units and sandfilled cylinders were used in this experiment, and they contained the same natural glaciofluvial coarse sand as was used in experiment 1 (see above). TOC, TSS, and turbidity in the circulating water were determined after the woodchip biofilter and after the sand filter

Fig. 2 A flowchart of the experimental setup, showing a fish rearing tank (FT), swirl separator, drum filter, fixed bed reactor (FBBR), moving bed reactor (MBBR), trickling filter (TF), a side-loop with a woodchip bioreactor (WCBR), and a sand filter (SF)

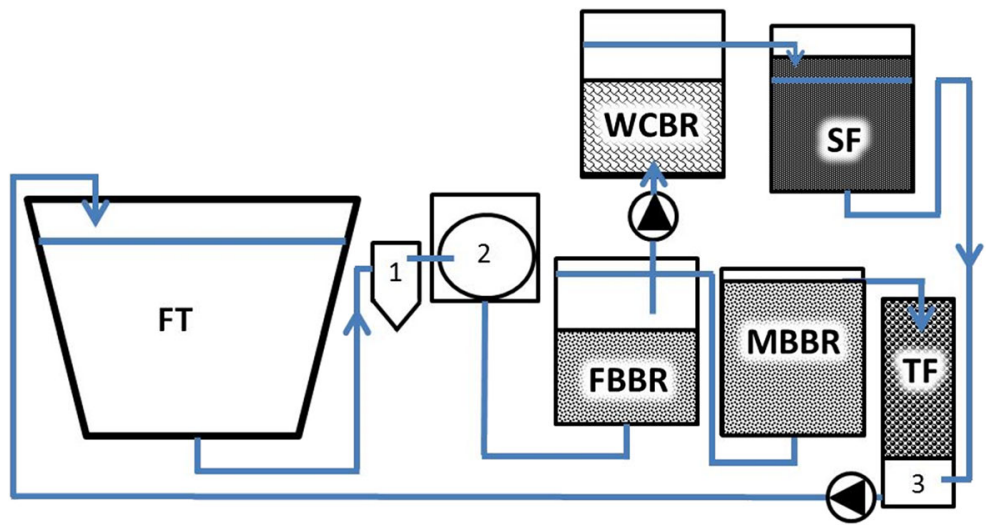


infiltration during the 15 th of June to 27 th of July 2018 at 1 -week intervals. The first determinations took place 2 weeks after the start of the experiment (week 3 from the start of the experiment). TOC, TSS, and turbidity were determined using the online measurement system by $\mathrm{S}$ ::can which was calibrated based on the laboratory measurements (Supplementary Fig. 1S, comparison of online and laboratory results).

Mean values and standard deviations were computed for the input and sand-filtrated parameters, and the paired one-tail $t$ test was used to study their statistical differences $(p<0.05)$. In order to study the relationships between the measured parameters in the input and sandfiltrated water, Pearson's correlation coefficients and the regression equations were determined. In order to study statistical differences in water parameters between the $25 \mathrm{~L} \mathrm{day}^{-1}$ and $40 \mathrm{~L}$ day $^{-1}$ infiltration, two-tailed $t$ test was used. We used the terms "the infiltration water" and "input water" for the water entering the sand filtration. By this, we referred to effluent water from RAS in experiment 1 and the circulating water after the woodchip biofilter in experiment 2. Additionally, we used the term "sand-filtrated water" for the water leaving the sand filtration (soil columns in experiment 1 and sand-filled cylinders in experiment 2).

\section{Results and Discussion}

\subsection{Experiment 1: Sand Filtration with Vertical Water Flow}

The mean TOC concentration (expressed as term sand$\mathrm{x}$, the average value from columns 1 and 2) was lower in the sand-filtrated water than in the input water on all sampling occasions excluding one occasion when the concentrations were close to each other (Fig. 3).

The mean TSS concentration was lower in the sandfiltrated water than in the input water on all sampling occasions except on the last occasion (Fig. 3).

There was a lot of variation in the turbidity values in the sand-filtrated water compared with the input water (Fig. 3).

The TOC removal was, however, quite small in the vertical water flow (experiment 1 , mean removal 6\%). If the removal cannot be increased with thicker sand layers or longer retention times, sand filtration would not be a suitable method on a production scale. A reason for the low TOC removal in vertical water flow was also the
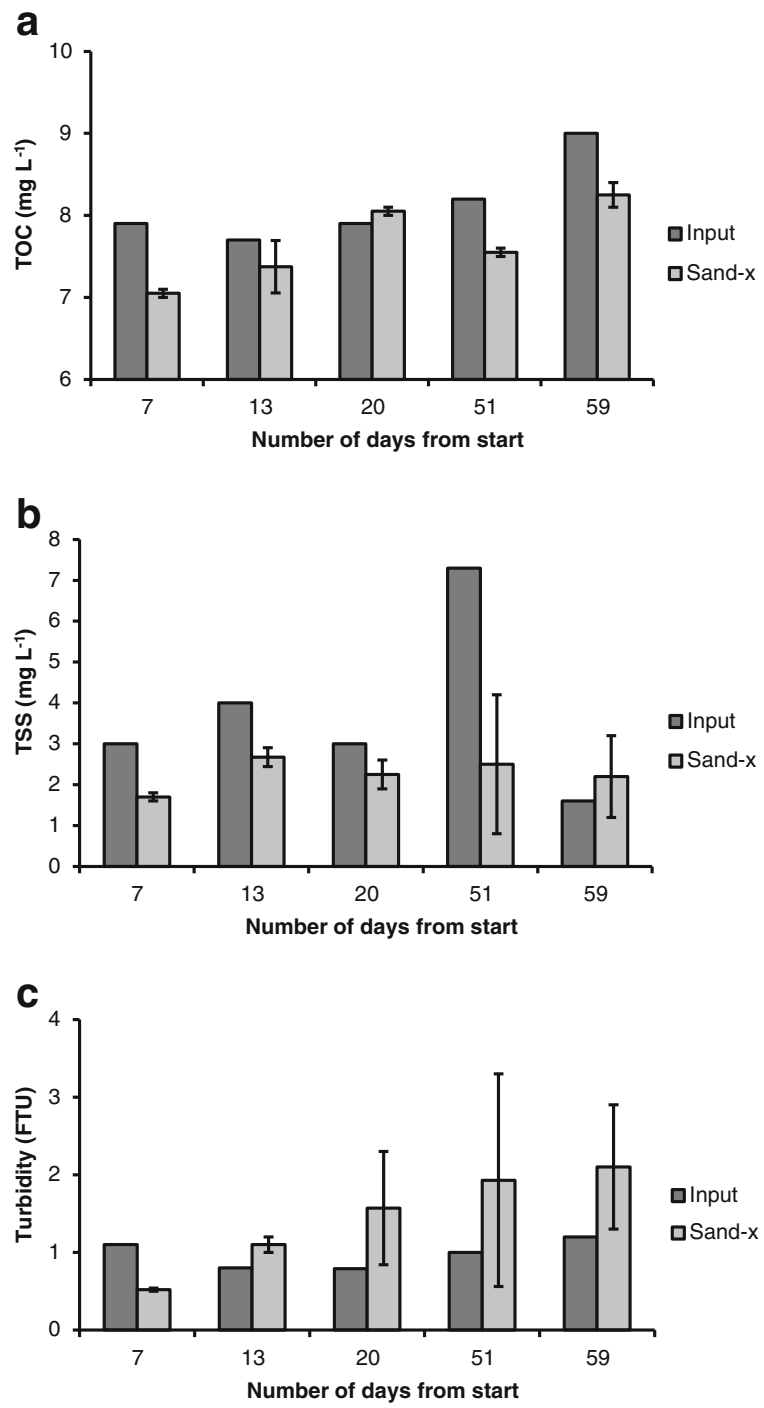

Fig. 3 TOC (a), TSS (b), and turbidity (c) by days from the start of experiment 1 in the infiltration (input, effluent from the aquaculture farm) and sand-filtrated water (sand-x) in the soil column experiment with vertical water flow. Sand- $\mathrm{x}=$ mean, columns 1 and 2. Error bars indicate the range between columns 1 and 2

fact that the TOC concentration of the effluent was already low, $8.14 \mathrm{mg} \mathrm{L}^{-1}$. Low TOC removal in unsaturated vertical water flow is in accordance with the data reported for the ARG process in the esker area in Southern Finland (Lindroos et al. 2002) and for a column test (Berggren et al. 1998). However, the removal of TSS was effective, $40 \%$ in vertical water flow as also reported by Helmisaari et al. (2003) related to the ARG process.

There were significant positive correlations $(p<$ 0.05 ) between the TOC concentrations in the input and 
a

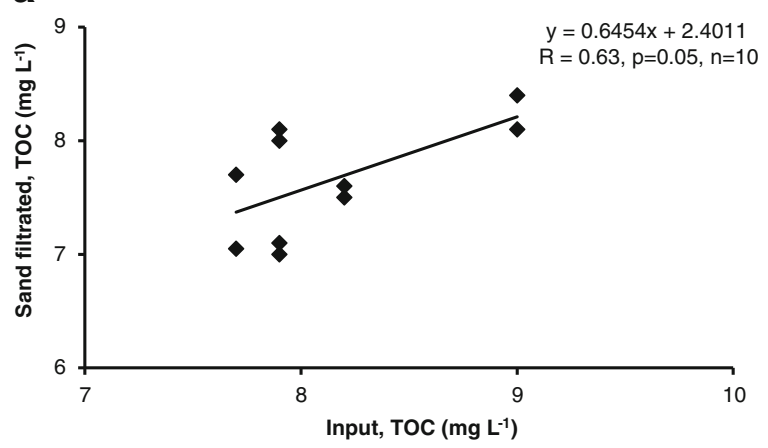

b

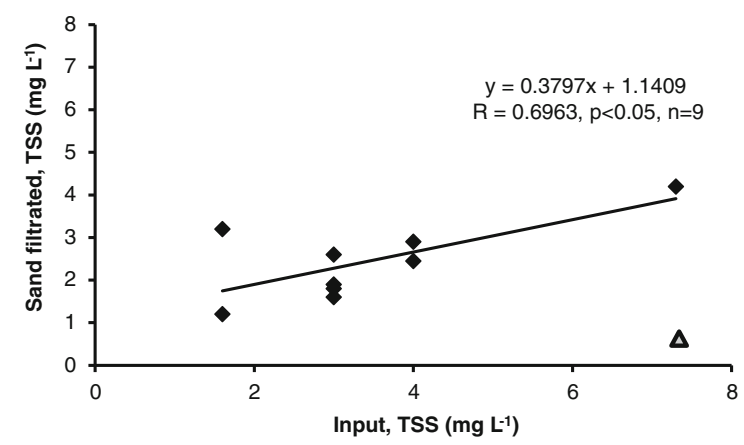

Fig. 4 Relationship between TOC (a) and TSS (b) in the infiltration (input, effluent from the aquaculture farm) and sand-filtrated water in the soil column experiment with vertical water flow. Outlier marked with a different symbol

sand-filtrated water and between the TSS concentration in the input and sand-filtrated water (Fig. 4; Supplementary Fig. 2S). In both cases, the concentrations were lower in the sand-filtrated than in input water. The relative decrease in concentrations (removal \%) for TSS increased with increasing TSS concentrations in input water (Supplementary Fig. 2S).

\subsection{Experiment 2: Sand Filtration with Water-Saturated Conditions}

The TOC and TSS concentrations and the turbidity values were lower in all measurement occasions in the sand-filtrated than in the input water for both the sand treatments 1 and 2 of the $25 \mathrm{~L} \mathrm{day}^{-1}$ and $40 \mathrm{~L}_{\text {day }}{ }^{-1}$ infiltration (Supplementary Fig. 3S, Fig. 5). The mean TOC, TSS, and turbidity values were significantly $(p<0.01)$ lower in the sand-filtrated than in the input water in $25 \mathrm{~L} \mathrm{day}^{-1}$ and $40 \mathrm{~L}^{-1 a y}{ }^{-1}$ infiltrations (Supplementary Tables $1 \mathrm{~S}$ and $2 \mathrm{~S}$ ). The mean decrease in concentrations for TOC, TSS, and turbidity did not
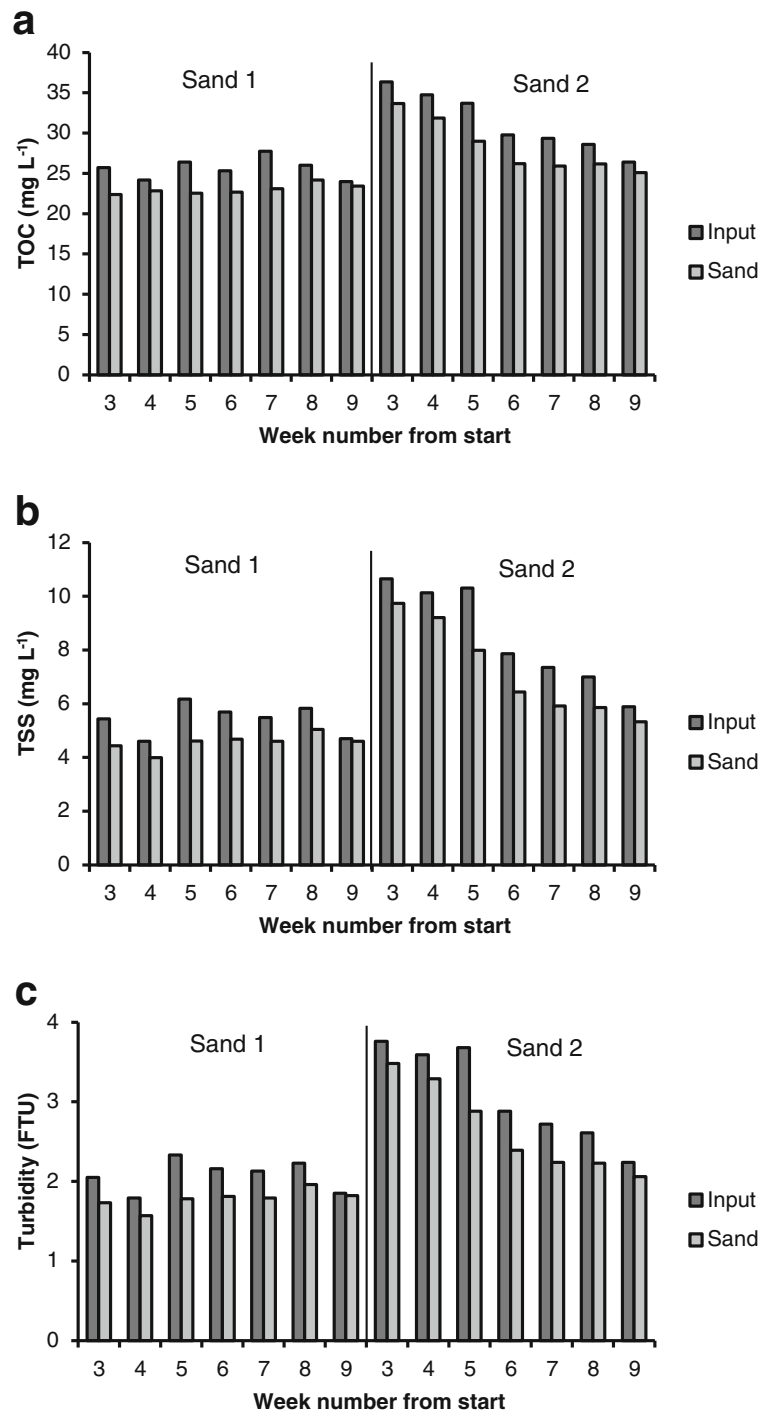

Fig. 5 TOC (a), TSS (b), and turbidity (c) by sampling week in the circulating water determined after the woodchip biofilter (input) and after the sand filter infiltration (sand) in experiment 2 with water-saturated conditions. Retention time in the sand filtration was 1.2 days, two replications $(1,2)$, infiltration $40 \mathrm{~L} \mathrm{day}^{-1}$

statistically differ between the $25 \mathrm{~L} \mathrm{day}^{-1}$ and $40 \mathrm{~L} \mathrm{day}^{-1}$ infiltrations with the retention time of 1.2 days (Fig. 6). There were significant positive correlations $(p<0.01)$ between the input and sand-filtrated values for TOC, TSS, and turbidity in the combined data, and the values were lower in the sand-filtrated water (Fig. 7, Supplementary Fig. 4S). The relative decrease in concentrations (removal \%) for TOC increased with increasing TOC concentrations in input water (Supplementary Fig. 4S). There was a positive 


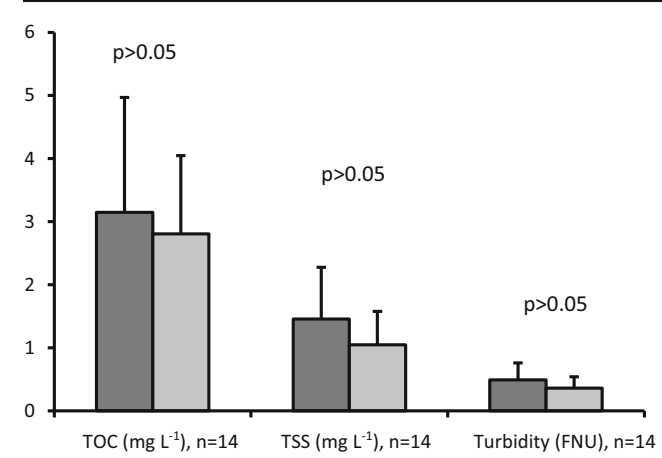

Fig. 6 Mean (S.D.) decrease of TOC, TSS, and turbidity in saturated sand filtration for the infiltrations of $25 \mathrm{~L} \mathrm{~d}^{-1}$ and $40 \mathrm{~L} \mathrm{~d}^{-1}$, retention time of $1.2 \mathrm{~d}$. According to two-tailed $t$ test, no significant difference was observed $(p>0.05)$

correlation $(p<0.01)$ for the decrease in the TOC concentrations and in the TSS concentrations in the combined data (Fig. 8). Similarly, there was a significant positive correlation $(p<0.01)$ between the decrease in the TOC concentration and in the turbidity values in the combined data (Fig. 8).

It seems possible to estimate quite accurately the TOC, TSS, and turbidity values in the sand-filtrated water in the water-saturated flow, and also TOC and TSS values in the vertical flow due to positive correlations between these parameters in the input and sandfiltrated water. The decrease in TOC concentrations in water-saturated flow was also related to the decrease in the TSS and turbidity values. For example, when the TOC decreased $4 \mathrm{mg} \mathrm{L}^{-1}$, the corresponding TSS decreased about $1.5 \mathrm{mg} \mathrm{L}^{-1}$ and the turbidity $0.5 \mathrm{FTU}$.

The mean TOC decrease in water-saturated flow was about $3 \mathrm{mg} \mathrm{L}^{-1}$ (11\%), TSS $1.2 \mathrm{mg} \mathrm{L}^{-1}$ (18\%), and turbidity 0.4 FTU (15\%) in 1.2 days for both infiltrations. Therefore, the retention time that was the same for both infiltrations ( $25 \mathrm{~L} \mathrm{day}^{-1}$ or $40 \mathrm{~L} \mathrm{day}^{-1}$ ) seemed to be a more important factor for the removal of TOC, TSS, and turbidity than the water flow velocity.

A decrease in the TOC concentration was observed in both of our experiments by sand filtration. This indicates that sand filtration would probably be a suitable method for the TOC removal also from aquaculture waters by using sand filters of larger volume. In our experiments, it was possible to study only the direction of retention processes but not the whole magnitude of the TOC removal from the aquaculture waters as the soil depth was only $0.5 \mathrm{~m}$ in vertical flow and the retention time 1.2 days in water-saturated flow.
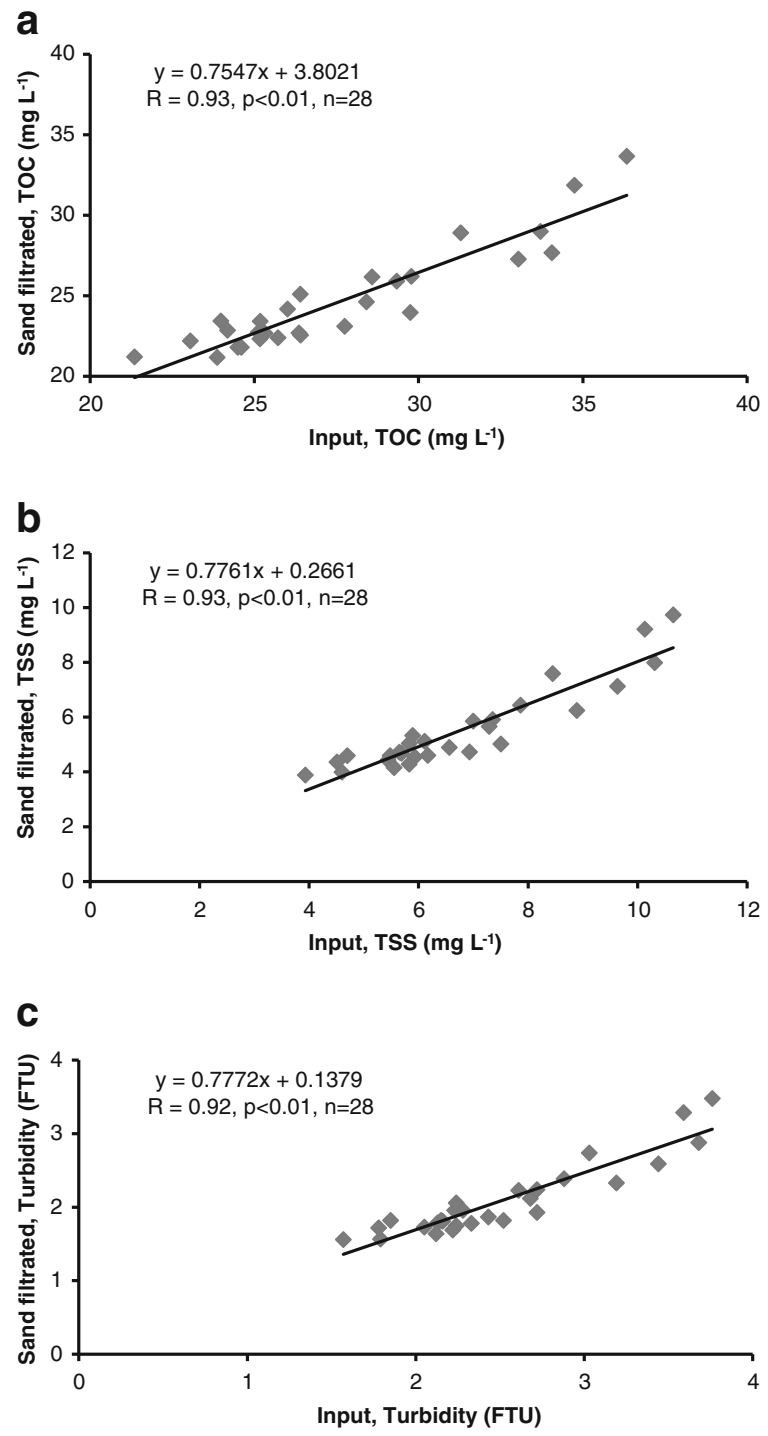

Fig. 7 Correlation between TOC (a), TSS (b), and turbidity (c) in the circulating water after the woodchip biofilter (input) and after the sand filter infiltration (sand filtrated) in experiment 2 with water-saturated conditions. Retention time in the sand filtration was 1.2 days. Combined data from the infiltrations of $25 \mathrm{~L} \mathrm{day}^{-1}$ and $40 \mathrm{~L} \mathrm{day}^{-1}$

Both sand filtration techniques (vertical water flow, water-saturated flow) seemed to be effective methods for the removal of suspended solids, since the removal was about $40 \%$ in the vertical water flow and $15-26 \%$ in watersaturated flow. Turbidity decreased in the water-saturated filtration (14-23\%). Online TSS and turbidity measurements used in saturated water flow correlated and were calibrated with the standard laboratory measurements (Supplementary Fig. 1S). There was, however, some variation in online determinations compared with the 
Fig. 8 Correlation between the decrease in TOC concentrations as well as a decrease in TSS concentrations and turbidity in water-saturated filtration. Retention time in the sand filtration was 1.2 days. Combined data from the infiltrations of $25 \mathrm{~L}_{\text {day }}{ }^{-1}$ and $40 \mathrm{~L} \mathrm{day}^{-1}$

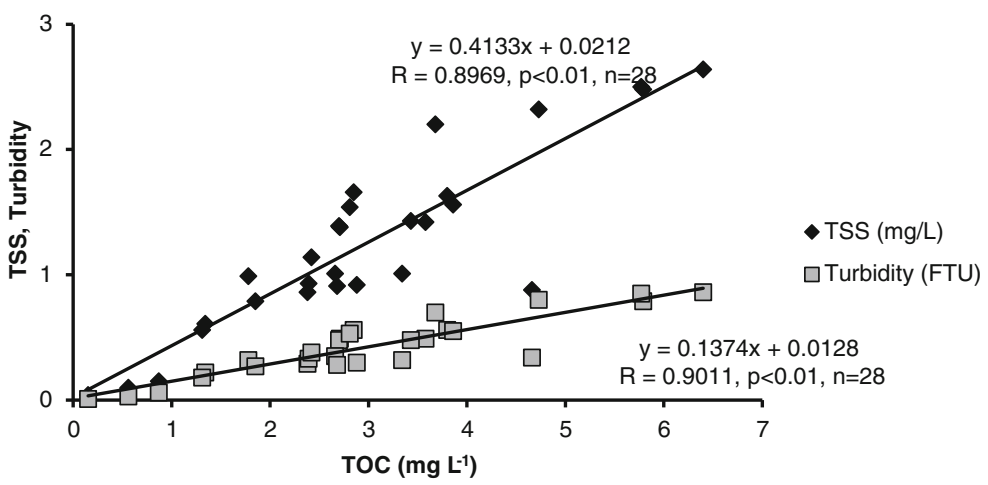

laboratory values. Despite that, TSS and turbidity values were systematically lower in sand-filtrated than in input water. Therefore, a decreasing trend in saturated sand filtration seemed to be clear, although there can be some deviation in relation to laboratory values.

Analytical methods were used for unsaturated flow (experiment 1) and online determinations for saturated water flow (experiment 2). Online TOC measurements correlated well and were calibrated with the laboratory measurements (Supplementary Fig. 1S). In watersaturated filtration (experiment 2), the TOC decrease was stronger (mean $11 \%$ ) both in $25 \mathrm{~L} \mathrm{day}^{-1}$ and $40 \mathrm{~L}_{\text {day }}{ }^{-1}$ infiltration. The results from both experiments ( 1 and 2 ) are not, however, fully comparable because the initial TOC levels in the effluent were not similar in vertical water flow and saturated flow. This is because our experiments were performed in association with (1) the untreated effluent from the RAS farm in 2017 and (2) effluent from the aquaculture RAS followed by woodchip treatment in 2018. The TOC decrease in effluent from the woodchip treatment of the RAS in saturated flow was, however, very similar to that found in the sand/gravel filtration in the ARG plants in Finland with the retention time of 1.2 days. Lindroos et al. (2002) reported that the DOC decrease in the groundwater zone was even $40 \%$ in the ARG plant in Southern Finland with a traveling distance of some $10 \mathrm{~m}$ and the retention time of 1 day (Helmisaari et al. 2003). Based on the large national compilation study (Helmisaari et al. 2003) performed in Finland on several ARG plants, the TOC decrease in the groundwater zone was 10-60\% during the first 5 days (Helmisaari et al. 2003). Our TOC results fall into this range. Kolehmainen et al. (2009) also reported a significant TOC removal in the infiltrated water in the first parts of the water-saturated zone in their experiments simulating the ARG process. In this respect, our observed TOC removal from the aquaculture farm effluent can be considered to be promising because this removal behaved quite similarly as that in the ARG plants with the retention time of 1.2 days. If the retention time can be increased and the TOC values in the aquaculture effluent continue to behave similarly as the TOC values in the infiltrated lake water at the Finnish ARG plants, more removal can be expected with increasing retention times (Helmisaari et al. 2003). In the ARG process of water flow through the sand and gravel containing overburden, the TOC removal is effective with increasing retention times and traveling distances (Lindroos et al. 2002). However, if the TOC retention cannot be increased with longer retention times in treating RAS farm effluent, sand filtration would not be a suitable method on a production scale.

Our results show that at least some parts of TSS and TOC are removable by sand filtration from RAS effluents. A mechanism behind the TSS removal was undoubtedly the physical retention into the soil material. In earlier studies related to the ARG process, it has been found that the processes responsible for the TOC removal are based partly on the molecular size of organic compounds that form TOC. For example, Lindroos et al. (2002) and Kolehmainen et al. (2009) found that fractions of large molecular size were removed more effectively than fractions of small molecular size from the infiltrated lake water in the ARG process (Kivimäki et al. 1998; Kolehmainen et al. 2007; Nissinen et al. 2001). In order to study the detailed process for the TOC removal from RAS effluents, it is important in future studies to determine the molecular size fractions of TOC as well as the chemical nature of TOC. In addition, the experiments with longer retention times than in the present study would be beneficial. In future studies, the facts that caused restrictions in our current experiments should be improved such as soil texture of the sand material. Material that contains smaller soil particles should also be studied. Thicker soil columns would be also beneficial. It would also be interesting to determine assimilable organic carbon (AOC) which is 
important in regulating microbial growth. Långmark et al. (2004) found that sand columns removed about $10 \%$ of TOC, which is close to the levels in our experiments, but AOC was removed much more effectively. The origin of particulate and dissolved organic matter is partly different in the RAS effluents compared with that in lake water, and therefore, it was interesting that TOC and TSS behaved quite similarly in our experiments in comparison with these parameters in lake water infiltration in ARG process. A similar kind of effective retention of suspended solids was also found in our study as in forest buffer zones along surface waters related to improving the water quality after forest management operations (Ring et al. 2018, 2019).

\section{Conclusions}

In conclusion, our experiments indicate that the sand filtration provides possibly a potential process for the removal of at least some parts of TOC, TSS, and turbidity from RAS farm effluents. The TOC removal in watersaturated flow was quite comparable with that in the ARG plants at the retention time of 1.2 days. The mean removal of $3 \mathrm{mg} \mathrm{TOC} \mathrm{L}{ }^{-1}, 1.2 \mathrm{mg} \mathrm{TSS} \mathrm{L}^{-1}$, and $0.4 \mathrm{FTU}$ in 1.2 days was similar for both studied infiltrations. Also, the TOC behavior was very similar in vertical water flow compared with that in the ARG process. The removal of TSS was quite effective in vertical and saturated water flow. The relative decrease in concentrations (removal \%) for TSS increased with increasing TSS concentrations in vertical flow and for TOC with increasing TOC concentrations in saturated flow. In future studies, detailed properties of TOC as well as the effect of longer retention times and the role of finer soil particles should be studied in order to determine in more detail the effectivity of sand filtration for RAS effluents.

Funding Information Open access funding provided by Natural Resources Institute Finland (LUKE).

\section{Compliance with Ethical Standards}

Conflict of Interest The authors declare that they have no conflict of interest.

Open Access This article is licensed under a Creative Commons Attribution 4.0 International License, which permits use, sharing, adaptation, distribution and reproduction in any medium or format, as long as you give appropriate credit to the original author(s) and the source, provide a link to the Creative Commons licence, and indicate if changes were made. The images or other third party material in this article are included in the article's Creative Commons licence, unless indicated otherwise in a credit line to the material. If material is not included in the article's Creative Commons licence and your intended use is not permitted by statutory regulation or exceeds the permitted use, you will need to obtain permission directly from the copyright holder. To view a copy of this licence, visit http://creativecommons.org/licenses/by/4.0/.

\section{References}

Akkanen, J., Vogt, R. D., \& Kukkonen, J. V. K. (2004). Essential characteristics of natural dissolved organic matter affecting the sorption of hydrophobic organic contaminants. Aquatic Sciences, 66, 171-177.

Alver, A., \& Kiliç, A. (2018). Catalytic ozonation by iron coated pumice for the degradation of natural organic matters. Catalysts, 8, 219.

Alver, A., Baştürk, E., \& Kiliç, A. (2018). Disinfection byproducts formation potential along the Melendiz River, Turkey; associated water quality parameters and non-linear prediction model. International Journal of Environmental Research, 12, 909-919.

Berggren, D., Nilsson, S. I., Blomberg, J. I., \& Larsson, U. (1998). Artificial groundwater recharge in Stockholm III. An experimental study of chemical processes in the unsaturated zone. In: Peters, J. H. et al. (Eds.). Artificial recharge of groundwater. Proceedings of the $3^{\text {rd }}$ International Symposium on Artificial Recharge Of Groundwater - TISAR '98 (pp. 387-389). A. A. Balkema, Rotterdam: Bookfield.

Bhatnagar, A., \& Sillanpää, M. (2017). Removal of natural organic matter (NOM) and its constituents from water by adsorption a review. Chemosphere, 166, 497-510.

Dalsgaard, J., \& Pedersen, P. B. (2011). Solid and suspended/ dissolved waste (N, P, O) from rainbow trout (Oncorynchus mykiss). Aquaculture, 313, 92-99.

Eronen, M. (1983). Late Weichselian and Holocene shore displacement in Finland. In D. E. Smith \& A. G. Dawson (Eds.), Shorelines and isostacy. Institute of British Geographers, Special Publication 16 (pp. 183-207). Academic Press.

Frycklund, C. (1995). Total organic carbon retention by filter sand in an infiltration pond for artificial groundwater recharge. Aqua Fennica, 25, 5-14.

Frycklund, C. (1998). Long-term sustainability in artificial groundwater recharge. In: Peters, J. H. et al. (Eds.). Artificial Recharge Of Groundwater. Proceedings of the $3^{\text {rd }}$ International Symposium on Artificial Recharge of Groundwater - TISAR '98 (pp. 113-117). A. A. Balkema, Rotterdam: Bookfield.

Frycklund, C., \& Jacks, G. (1997). Iron and artificial recharge of groundwater. Boreal Environment Research, 2, 171-181.

Gopal, K., Tripathy, S. S., Bersillon, J. L., \& Dubey, S. P. (2007). Chlorination byproducts, their toxicodynamics and removal from drinking water. Journal of Hazardous Materials, 140, 1-6.

Helmisaari, H.-S., Kitunen, V., Lindroos, A.-J., Lumme, I., Monni, S., Nöjd, P., Paavolainen, L., Pesonen, E., Salemaa, M., \& Smolander, A. (1998). Sprinkling infiltration in Finland: 
effects on forest soil, percolation water and vegetation. In: Peters, J. H. et al. (Eds.). Artificial recharge of groundwater. Proceedings of the $3^{\text {rd }}$ International Symposium on Artificial Recharge of Groundwater - TISAR ‘98 (pp. 243-248). A. A. Balkema, Rotterdam: Bookfield.

Helmisaari, H.-S., Illmer, K., Hatva, T., Lindroos, A.-J., Miettinen, I., Pääkkönen, J., \& Reijonen, R., (Eds.) (2003). Tekopohjaveden muodostaminen: imeytystekniikka, maaperäprosessit ja veden laatu. The Finnish Forest Research Institute, Research Papers 992. (In Finnish).

Kivimäki, A.-L., Lahti, K., Hatva, T., Tuominen, S. M., \& Miettinen, I. T. (1998). Removal of organic matter during bank filtration. In: Peters, J. H. et al. (Eds.). Artificial recharge of groundwater. Proceedings of the $3^{\text {rd }}$ International Symposium on Artificial Recharge of Groundwater - TISAR '98 (pp. 107-112). A. A. Balkema, Rotterdam: Bookfield.

Kolehmainen, R. E., Langwaldt, J. H., \& Puhakka, J. A. (2007). Natural organic matter (NOM) removal and structural changes in the bacterial community during artificial groundwater recharge with humic lake water. Water Research, 41, 2715-2725.

Kolehmainen, R. E., Tiirola, M., \& Puhakka, J. A. (2008). Spatial and temporal changes in Actinobacterial dominance in experimental artificial groundwater recharge. Water Research, 42, 4525-4537.

Kolehmainen, R. E., Kortelainen, N. M., Langwaldt, J. H., \& Puhakka, J. A. (2009). Biodegradation of natural organic matter in long-term continuous-flow experiments simulating artificial groundwater recharge for drinking water production. Journal of Environmental Quality, 38, 44-52.

Långmark, J., Storey, M. V., Ashbolt, N. J., \& Stenström, T. A. (2004). Artificial groundwater treatment: biofilm activity and organic carbon removal performance. Water Research, 38, 740-748.

Lindholm-Lehto, P. C., Pulkkinen, J. T., Kiuru, T., Koskela, J., \& Vielma, J. (2020). Water quality in recirculating aquaculture system using woodchip denitrification and slow sand filtration. Environmental Science and Pollution Research. https://doi.org/10.1007/s11356-020-08196-3.

Lindroos, A.-J., Kitunen, V., Derome, J., \& Helmisaari, H.-S. (2002). Changes in dissolved organic carbon during artificial recharge of groundwater in a forested esker in southern Finland. Water Research, 36, 4951-4958.

Lindroos, A.-J., Derome, J., Mustajärvi, K., Nöjd, P., Beuker, E., \& Helmisaari, H.-S. (2008). Fluxes of dissolved organic carbon in stand throughfall and percolation water in 12 boreal coniferous stands on mineral soils in Finland. Boreal Environment Research, 13(suppl. B), 22-34.

Lindroos, A.-J., Tamminen, P., Heikkinen, J., \& Ilvesniemi, H. (2016). Effect of clear-cutting and the amount of logging residues on chemical composition of percolation water in spruce stands on glaciofluvial sandy soils in southern Finland. Boreal Environment Research, 21, 134-148.

Matilainen, A., \& Sillanpää, M. (2010). Removal of natural organic matter from drinking water by advanced oxidation processes. Chemosphere, 80, 351-365.

Michalzik, B., Kalbitz, K., Park, J. H., Solinger, S., \& Matzner, E. (2001). Fluxes and concentrations of dissolved organic carbon and nitrogen - a synthesis for temperate forests. Biogeochemistry, 52, 173-205.
Nissinen, T. K., Miettinen, I. T., Martikainen, P. J., \& Vartiainen, T. (2001). Molecular size distribution of natural organic matter in raw and drinking waters. Chemosphere, 45, 865-873.

Nöjd, P., Lindroos, A.-J., Smolander, A., Derome, J., Lumme, I., \& Helmisaari, H.-S. (2009). Artificial recharge of ground water through sprinkling infiltration: impacts on forest soil and the nutrient status and growth of Scots pine. Science of the Total Environment, 407, 3365-3371.

Peters, J. H. et al. (Eds.). (1998). Artificial recharge of groundwater. Proceedings of the $3^{\text {rd }}$ international symposium on artificial recharge of groundwater - TISAR ' 98 . A. A. Balkema, Rotterdam: Bookfield.

Piirainen, S. (2002). Nutrient fluxes through a boreal coniferous forest and the effects of clear-cutting. The Finnish Forest Research Institute, Research Papers 859.

Piirainen, S., Finer, L., Mannerkoski, H., \& Starr, M. (2002). Effects of forest clear-cutting on the carbon and nitrogen fluxes through podzolic soil horizons. Plant and Soil, 239, 301-311.

Pulkkinen, J. T., Kiuru, T., Aalto, S. L., Koskela, J., \& Vielma, J. (2018). Startup and effects of relative water renewal rate on water quality and growth of rainbow trout (Oncorhynchus mykiss) in a unique RAS research platform. Aquacultural Engineering, 82, 38-45.

Ring, E., Andersson, E., Armolaitis, K., Eklöf, K., Finer, L., Gil, W., Glazko, Z., Janek, M., Lode, E., Libiete, Z., Malek, S., \& Piirainen, S. (2018). Good practices for forest buffers to improve water quality in the Baltic region. Arbetsrapport, 995, 59 p-2018.

Ring, E., Andersson, E., Armolaitis, K., Eklöf, K., Finer, L., Gil, W., Glazko, Z., Janek, M., Libiete, Z., Lode, E., Malek, S., \& Piirainen, S. (2019). Hyvät käytännöt suojavyöhykkeiden muodostamiseen vesistöjen varsille Itämeren alueellaKäsikirja. Luonnonvara- ja biotalouden tutkimus 10/2019, 23 p. (In Finnish).

Starr, M., \& Lindroos, A.-J. (2006). Changes in the rate of release of $\mathrm{Ca}$ and $\mathrm{Mg}$ and normative mineralogy due to weathering along a 5300-year chronosequence of boreal forest soils. Geoderma, 133, 269-280.

Starr, M., \& Ukonmaanaho, L. (2004). Levels and characteristics of TOC in throughfall, forest floor leachate and soil solution in undisturbed boreal forest ecosystems. Water, Air and Soil Pollution: Focus, 4, 715-729.

Thurman, E. M. (1985). Humic substances in groundwater. In G. R. Aiken, D. M. McKnight, R. L. Wershaw, \& P. MacCarthy (Eds.), Humic Substances in Soil, Sediment and Water (pp. 87-103). John Wiley \& Sons, Inc..

Ukonmaanaho, L., Starr, M., Lindroos, A.-J., \& Nieminen, T. M. (2014). Long-term changes in acidity and DOC in throughfall and soil water in Finnish forests. Environmental Monitoring and Assessment, 186, 7733-7752.

Wu, Y., Clarke, N., \& Mulder, N. (2010). Dissolved organic carbon concentrations in throughfall and soil waters at level II monitoring plots in Norway: short- and long-term variations. Water, Air and Soil Pollution, 205, 273-288.

Publisher's Note Springer Nature remains neutral with regard to jurisdictional claims in published maps and institutional affiliations. 